\title{
Dziennik Danuty S. jako tożsamościowa gra w klasy
}

Anna Pawlik

TEKSTY DRUGIE 2018, NR 6, S. 322-340

DOI: $10.18318 /$ td.2018.6.22

W 1962 roku Komitet Badań nad Współczesnością PAN i Zakład Socjologii Wsi PAN ogłosiły konkurs we współpracy ze Związkiem Młodzieży Wiejskiej i Ludową Spółdzielnią Wydawniczą pod kierownictwem Józefa Chałasińskiego.

Wystosowano drukowaną w czasopismach wiejskich odezwę Do mtodego pokolenia wsi Polski Ludowej, bardzo szeroko zakreślającą potencjalnych odbiorców i odbiorczynie konkursu. Swoje pamiętniki mogły przesyłać osoby urodzone i wychowane na wsi lub w małych miasteczkach, zamieszkujące aktualnie wieś lub miasto, jak również te, które życie na wsi wybrały. Autorami i autorkami mogły być zatem osoby pracujące w gospodarstwie rodziców lub własnym, te które wyjechały do miasta i rozpoczęły tam nowe życie, ale także inteligencja wiejska - lekarze i nauczyciele'.

1 Odezwa zwracała się zarówno do kobiet jak i mężczyzn. Pamiętniki nadesłane przez kobiety stanowiły $48 \%$ ogółu.
Anna Pawlik - mgr,

Członkini Zespołu Archiwum Kobiet, uczestniczka projektu $\mathrm{NPRH}$ „Archiwum Kobiet: Piszące" realizowanego w latach 2013-2018 w Instytucie Badań Literackich PAN, kontakt: a.e.pawlik@ gmail.com 
Organizatorzy mieli oczekiwania stylistyczne i formalne. Prosili o zwięzłe, konkretne i szczere wypowiedzi, chronologicznie relacjonujące przebieg dotychczasowego życia autora, począwszy od lat szkolnych, poprzedzone opisem losów najbliższej rodziny. Wskazówki dane w odezwie konkursowej były bardzo szerokie, w warstwie formalnej natomiast w znaczący sposób ograniczały pole możliwości.

Napłynęło około 5500 prac, a niektóre z nich zostały opublikowane w Młodym pokoleniu wsi Polski Ludowej. To dziewięciotomowe dzieło miało w założeniu Chałasińskiego nawiązywać do badań przedwojennych uwieńczonych wydaniem Młodego pokolenia chłopów. Szczególnie istotne było to w kontekście warunków życia na polskiej wsi. Konceptualizacja nowych badań jako pewnego rodzaju kontynuacji poprzedniego badania pozwalała na ujrzenie całości obrazu, na który miał składać się skok cywilizacyjny polskiej wsi, poprawa warunków życia na wsi, a także w mieście w sytuacji konieczności poszukiwania nowej drogi życia².

W Archiwum Polskiej Akademii Nauk w Warszawie możemy znaleźć w formie maszynopisu sprzed cięć redaktorskich i cenzorskich niektóre z prac nadesłanych na konkurs, a także prace nieopublikowane. Jest wśród nich fragment dziennika szesnastoletniej Danuty S., jednej z najmłodszych uczestniczek tego konkursu. Na tle pozostałych wspomnień praca ta wydaje się wyjątkowa. Zwraca uwagę szeroko pojętą literackością. Ten aspekt jej pracy konkursowej stanowi przedmiot mojej interpretacji.

Dziennik Danuty S. jest hybrydą gatunkową. Mamy tutaj do czynienia zarówno z odniesieniami do rzeczywistości, jak i takimi aspektami fikcjonalności, które zatrzymują naszą uwagę na zabiegach retorycznych tej wypowiedzi ${ }^{3}$. Jest to o tyle istotne, że opis konkursu wyraźnie wskazywał na formę autobiograficzną o charakterze wspomnień, czyli relację z wydarzeń z przeszłości. Autorka nie uwzględniła instrukcji organizatorów - nie powróciła pamięcią do wydarzeń z dzieciństwa, nie opisała losów swojej rodziny.

2 Cenzura, która funkcjonowała w tamtych latach, była wobec przygotowanego zbioru prac dość liberalna, jak twierdzi Stanisław Siekierski, który brał udział w opracowywaniu materiałów konkursowych. Nie mogły zostać opublikowane prace, które zdawały relacje z sytuacji polskich rodzin na tzw. Kresach Wschodnich po przejęciu tych terenów przez ZSRR. S. Siekierski Recepcja "Młodego pokolenia chłopów” Józefa Chałasińskiego, „Przegląd Humanistyczny” 2008 $\operatorname{nr} 6$ (411), s. 8.

3 Problem hybrydyczności jako cechy dziennika, w tym wypadku dziennika Zofii Nałkowskiej, pojawia się w książce Magdaleny Marszałek Życie i papier: autobiograficzny projekt Zofii Nałkowskiej: Dzienniki 1899-1954, Universitas, Kraków 2004. 
Jej tekst to dziennik - ma formę szeregu notatek, z których każda oznaczona jest datą wpisu, a dystans czasowy do opisywanych wydarzeń jest niewiel$\mathrm{ki}^{4}$, na co wskazują użyte przez nią formy komunikujące czas (np. „wczoraj”, „dzisiaj”), jak również informacje o oczekiwanych z nadzieją lub niepokojem mających nadejść wydarzeniach. Danuta S. na bieżąco notuje wydarzenia z życia, zapisuje rozmowy z koleżankami i kolegami i refleksje dotyczące czytanych właśnie książek i artykułów w czasopismach. Skoncentrowana jest na sobie, swoich doświadczeniach i emocjach. Pisze najczęściej co dwa, trzy dni, ale zdarzają się jej przerwy miesięczne, które mogą oznaczać miejsca poddane autocenzurze podczas przepisywania tekstu na konkurs lub zabiegi konstrukcyjne. Możemy na ten temat snuć jedynie przypuszczenia.

Oryginalny tekst, czyli tekst pierwotnego dziennika, z którego Danuta S. przepisała wysłany na konkurs fragment, istnieje/istniał, o czym dowiadujemy się z ostatniego dramatycznego wpisu dokumentującego samowolę współlokatorki z internatu, która w tajemnicy przeczytała jej diariusz i opowiedziała o jego treści innej koleżance. „Autentyczny” znaczy tu tyle co materialny, towarzyszący codziennej praktyce diarystycznej, przedmiot.

"Mój pamiętnik" - pisze o nim Danuta, odróżniając go od „tego pamiętnika", czyli tekstu dostępnego w archiwum. Wpis ten musiał zostać dodany podczas przepisywania i prawdopodobnej redakcji rękopisu. Użyte przez nią słowa wskazują na różnicę między dwoma tekstami - „moim pamiętnikiem” a "tym pamiętnikiem". Sugerują, zdradzając istnienie pierwowzoru dziennika, że dziennik, w którym je zapisano, został „spreparowany" na użytek konkursu.

\section{Literackość}

Dziennik Danuty S. obejmuje okres od 20 lutego 1960 do 11 listopada 1961 roku. Rozpoczyna się niecały rok przed ogłoszeniem konkursu. Autorka, pisząca pod pseudonimem „Anna Czywiž”, była wówczas nastoletnią dziewczyną, uczennicą szkoły średniej z internatem dla dziewcząt, kierowanej przez zakonnice. Wakacje spędzała, pomagając rodzicom na roli. Była oczytana i inteligentna, a literatura odgrywała w jej życiu dużą rolę. Mann, Zola, Knut Hamsun, Selma Lagerlöf, Prus i Dąbrowska to niektóre wymieniane przez nią nazwiska pisarzy i pisarek, których twórczość miała dla niej na tyle duże znaczenie, że zdecydowała się napisać o nich w dzienniku. Niektóre z zapisków

\footnotetext{
4 N. Lemann Dziennik, w: Słownik rodzajów i gatunków literackich, red. G. Gazda, S. Tynecka-Makowska, PWN, Warszawa 2006, s. 191-194.
} 
dotyczących tych lektur można określić mianem hypomneumata ${ }^{5}$, są nimi cytaty i refleksje ogólne na tematy przedstawione w danej książce. Wiele z nich natomiast dostarcza jej materiału do interpretacji własnych uczuć i doświadczeń. Zarówno pierwszy, jak i drugi rodzaj zapisków z lektury to czynione po omacku próby ustalenia własnej tożsamości.

Celem postawionym uczestniczkom i uczestnikom konkursu przez Komisję Badań nad Pamiętnikarstwem PAN było pozbawione ozdobników, jak najprostsze wypowiedzenie prawdy o własnym życiu. Wybrane do druku pamiętniki miały złożyć się na obraz życia młodego pokolenia żyjącego na wsi. Przede wszystkim organizatorzy oczekiwali dbałości o adekwatność formy. Za wartościowy uważano tekst, który dzięki zastosowaniu realistycznych środków wyrazu potwierdzał swoją wiarygodność. Danuta S. postępuje na przekór tym zaleceniom, stara się o literackość swojego diarystycznego pisarstwa a „literackość (pojmowana tradycyjnie jako zespół wartości stylistycznych i fikcjonalizacyjnych) zdaje się z góry dyskwalifikować prawdziwość przekazu"6. Wybiera środki ekspresji właściwe literaturze - dialogi, porównania, powtórzenia, apostrofy. Dbałość o estetykę wypowiedzi wyraża się również w rytmie, melodii zdań i doborze poszczególnych słów. Przywodzi na myśl stylistykę powieści dla dziewcząt z okresu PRL'. Ekspresja literacka tego dziennika wynika z rzeczywistych zdolności autorki, które ta chce silnie wyeksponować. Dzięki nim podkreśla swoją wyjątkowość i upewnia się w swojej odmienności.

Jak wspomniałam, praca konkursowa Danuty S. nosi cechy zarówno dziennika, jak i tekstu literackiego. Nie chodzi tylko o to, że dokumenty nieliterackie (spoza pola kultury literackiej) mogą być estetycznie podobne w warstwie językowej do tekstów literackich. Dziennik Danuty jest przykładem tekstu mającego ambicje artystyczne. Należy potraktować go jako osobistą sygnaturę, wyraz dążeń i marzeń autorki.

Decyzja o przystąpieniu do konkursu dała autorce okazję do przepisania fragmentu swojego dziennika. Ten gest powtórzenia pociągał za sobą decyzje redaktorskie, tyle że tekst był także swoistym lustrem redaktorki, w którym

5 M. Foucault Szaleństwo i literatura. Powiedziane, napisane, wyb. i opr. T. Komendant, przeł. B. Banasiak i in., Aletheia, Warszawa 1999, s. 306-311.

6 M. Delaperrière Świadectwo jako problem literacki, „Teksty Drugie” 2006 nr 3, s. 59-70.

7 Z tych, których czytelniczką mogła być Danuta S., ze względu na ich datę wydania można wymienić następujące: Słoneczniki Haliny Snopkiewicz, Godzina pąsowej róży Marii Krüger, Kochana rodzinka i ja Natalii Rolleczek, Tancerze Elżbiety Jackiewiczowej. 
zobaczyła m.in. skomplikowaną, ale też inteligentną i oczytaną dziewczynę. Zobaczyła także, że sama siebie taką stworzyła, że końcowy obraz zależy od jej konstrukcyjnych zdolności. Pisanie i przepisywanie skutkuje rozpoznaniem siebie jako podmiotu, jednostki twórczej i sprawczej oraz uzyskaniem świadomości, do czego może posłużyć jej używane przez nią medium. Funkcji zasadniczej tego dziennika możemy zatem upatrywać w rozpoznaniu własnych możliwości twórczych, co ma konsekwencje nie tylko tekstowe, ale przede wszystkim psychologiczne. Trudno powiedzieć, czy to działanie na tekście dziennika miało również znaczenie krytyczne służące przewartościowaniu własnych postaw, interakcji i pamięci o nich.

Elementy zewnętrzne dziennika - opis teczki i dokumentów w archiwum, pozwalają nam na opisanie jego funkcjonowania jako dokumentu. Dzięki temu dowiadujemy się, że tekstowa Anna Czywiż w rzeczywistości nazywa się Danuta S. Każdy pamiętnik w teczce w archiwum jest opatrzony nagłówkiem z prawdziwym imieniem i nazwiskiem autorki i miejscem zamieszkania, które nie różniły się w przypadku innych autorek od tych podanych w tekście pamiętnika ${ }^{8}$. Widzimy zatem, że była to decyzja S. To posunięcie performatywnie buduje dystans między realną „ja” a "ja” tekstową. Pseudonim czyni z Anny Czywiż bohaterkę tekstu, a Danutę S. czyni jego autorką. Jednakże nie chodzi tu o wyznaczenie granicy między autorką i bohaterką. To nadal jest dziennik Danuty S., którego autentyczność autorka poświadczyła, wysyłając go na konkurs. W dalszej części tekstu personalia Anna Czywiż i Danuta S. będą podawane jednocześnie z użyciem ukośnika (np. Anna/Danuta). Ukośnik nie sugeruje, że są one tożsame i mogą być używane wymiennie, jego rolą jest zasygnalizowanie, że są one jednoczesne, że obie mają swój udział w performowaniu tożsamości, która jest zarazem tekstowa, jak i rzeczywista.

Janet Verner Gunn powołując się na założenia Georges'a Gusdorfa stwierdza, że choć właściwego sensu autobiografii ${ }^{9}$ należy szukać w jej funkcji antropologicznej, a nie literackiej, należy ją zlokalizować i skontekstualizować w sposób pozwalający ów wymiar antropologiczny uchwycićn ${ }^{10}$. Literackość dziennika Danuty S. nie jest istotna bez owego aspektu antropologicznego, który pozwala nam uchwycić literackośćjako działanie, którego stawką jest tożsamość autorki w jej wymiarze społecznym, kulturowym, genderowym i seksualnym.

8 W publikowanych pamiętnikach dane były zmieniane.

9 Każdego autobiograficznego pisania.

10 J.V. Gunn Sytuacja autobiograficzna, w: Autobiografia, red. M. Czermińska, słowo/obraz terytoria, Gdańsk 2009, s. 152. 


\section{Dziewczyny z pensji, dziewczyny z internatu}

Dobór tematów, natężenie emocji, styl zbliżają dziennik Danuty S. do innych dzienników młodych dziewcząt. Utrzymany jest on w konwencji, której ramę wyznacza specyficzna emocjonalność wieku dorastania i kulturowe oczekiwania wobec młodych kobiet. Jest to emocjonalność, w której to, co się wydarza, dzieje się "na zawsze”, a wiara w szczęście bywa bezpowrotnie tracona. Wpis Zofii Matuszewiczówny z 27 października 1816 roku, mimo że pochodzi z kulturowo i historycznie innej epoki, równie dobrze mógłby znaleźć się w dzienniku S.:

Jakież to są we mnie dziwne kontrasta! Wczoraj tańczyłam do upadłego, dziś potrzebuję całej siły woli, by się wstrzymać od łez. Gdybym wszakże miała oddzielić i zważyć moje różne uczucia - przeważałby smutek. Jeśli jest to igraszka - to była okrutną! Takie właśnie miałam w duszy spokój i cieszyłam się nim tak bardzo, bo tego dobra najmniej dotąd użyłam. Spokoju mi najwięcej żal. ${ }^{11}$

Kiedy mówimy o podobieństwie dzienników, pisanych w okresie życia między młodością a dorosłością, z tak odmiennych czasów i środowisk, musimy pamiętać o niebezpieczeństwach łatwych porównań i związanych z tym anachronizmów. Ale w tym wypadku nie o ścisłe podobieństwo jednak chodzi.

Philippe Lejeune w tekście Dziewczęce „ja”. (O dziennikach panien z XIX wieku) pisze o dziennikach, których wspólną cechą jest wiek i stan cywilny ich autorek, jako o odrębnym gatunku. Piszące je dziewczęta należały najczęściej do arystokracji lub burżuazji francuskiej. Praktyka diarystyczna była bardzo często czynnością inspirowaną bądź nakazaną i kontrolowaną przez rodziców. Tradycyjne dzienniki panieńskie to, jak pisze Lejeune, „dzienniki okresu oczekiwania"12. Pełne lęku wypatrywanie kandydata na męża Lejeune porównuje do oczekiwania na ogłoszenie wyroku. Dziennik miał być towarzyszem w tym oczekiwaniu, pomóc w osłabieniu lęku i w przygotowaniu

11 Pamiętnik Zofii z Matuszewiczów Kickiej 1796-1822, [s. I.] 1910; druk fragmentów na podstawie opracowania T. Wodzickiej Z dzienniczka zakochanej (1816), w: Opowieści dziewczęce. Ustępy z pamiętników młodych panien (1776-1886), oprac. S. Wasylewski, Wydawnictwo Literackie, Kraków 1957, s. 49-70.

12 P. Lejeune "Drogi zeszycie...", "drogi ekranie...". O dziennikach osobistych, przeł. A. Karpowicz, M. i P. Rodakowie, Wydawnictwa UW, Warszawa 2011, s. 212. 
do nowej sytuacji życiowej ${ }^{13}$. W ramach tego samego gatunku istniała inna droga, która prowadziła nie do adaptacji, lecz do kontestacji i emancypacji. Dziennik jest tutaj nie tylko świadectwem tej drogi, ale jej „instrumentem/ wehikułem/maszyną parową. Statkiem pirackim/ośmiornicą i Aldebaranem dziewczęcych tęsknot, oczami zamienionymi w nieposłuszne słowa"14. Służy do doskonalenia warsztatu literackiego, jest miejscem pracy intelektualnej, kształtowania się indywidualności, miejscem, w którym młoda kobieta mogła zaistnieć jako autonomiczna jednostka ${ }^{15}$. Autorki tych dzienników, pisanych przez dłuższy okres życia, rezygnowały z małżeństwa na rzecz pracy intelektualnej lub artystycznej. Tradycyjne dzienniki kończyły się wraz z zawarciem małżeństwa.

Wrażenie podobieństwa między dziennikiem S. a dziennikami panieńskimi jest być może uruchamiane przez odczytywane z nich świadectwa zmiennej historycznie, ale istniejącej w obu tych światach opresji wobec kobiet, ale również przez wspólnotę wieku, który jest okresem inicjacji w dorosłość i w obu przypadkach, jak się okazuje, jest to okres szczególny. To nie pokrewieństwo wywiedzione z przesłanek ściśle badawczych, tylko rodzaj doświadczenia, które Lejeune opisuje następująco:

Choć urodziłem się w roku 1938 i jestem osobnikiem płci męskiej, poczułem, że między dziennikiem Claire Pic a moim własnym, młodzieńczym dziennikiem istnieją powinowactwa tak głębokie, że pozwoliło mi to następnie doświadczyć bliskości również z tym, co było, mimo wszystko różne. ${ }^{16}$

Umiejscowienie dziennika Danuty S. w tradycji dzienników panieńskich pozwala zobiektywizować jej doświadczenie, a przez odwołanie się do pewnego zbiorowego przeżycia uniwersalizuje je, nadając jej podmiotowość. Z drugiej strony dzienniki mimo cech wspólnych są jednak wyrazem indywidualności. Lektura dzienników młodych dziewcząt pochodzących z odległych czasów i odmiennych warstw społecznych jako jednego gatunku umożliwia jednoczesne spojrzenie na to, co wspólne i powtarzalne

Tamże, s. 214 .

M. Rudaś-Grodzka, niepublikowany tekst poetycki, Warszawa 2018. 
i na to, co jednostkowe; zobaczyć historię pewnego doświadczenia (uhistorycznić je).

\section{Chłopka, nie-chłopka}

Danuta S. pochodziła z chłopskiej rodziny i choć zagadnienie pochodzenia społecznego nie pojawia się w dzienniku bezpośrednio, to jest to jeden z najważniejszych problemów autorki. Nie są w stanie przysłonić go tematy uniwersalne, takie jak miłość, przyjaźń, zło, szczęście, które autorka chętnie podejmuje. Przynależność do warstwy chłopskiej jest postrzegana przez nią jako coś zastanego, co nie podlega przekształceniom, a związane jest z trudem i cierpieniem. Można odnieść wrażenie, że Danuta/Anna chciałaby od tego uciec.

Pierwsza wzmianka o pochodzeniu społecznym Danuty S./Anny Czywiż pochodzi z przedstawionej w formie dialogu sytuacji, w której została wywołana do „odkrycia” swojej tożsamości lub do decyzji identyfikacyjnej. Wydarzyło się to podczas zabawy tanecznej, na której towarzyszył jej nowo poznany chłopak. W międzyczasie jego „eskorta” zaczęła jej ciążyć. Adoratorowi trudno jednak było pogodzić się z odrzuceniem, skierował więc do niej ironiczne pytanie o pochodzenie sugerujące jej arystokratyczną genealogię.

Pytanie o szlachectwo było tylko retorycznym zabiegiem, mającym ujawnić jej rzekome poczucie wyższości oraz wyrazem jego urażonej dumy. Chłopak zignorował jej odpowiedź, w której ujawniła swoje pochodzenie, przekonany, że nie może być dziewczyną ze wsi. Sitek rozpisuje tę sytuację, budując napięcie wokół kwestii chłopskiego pochodzenia. Prowadzi, choć być może bez szczególnej chęci, grę, w której stawką jest jej wizerunek. Ona, "chłopka z Nałęki" tak się przedstawia adoratorowi, jest inna i chce być inna niż reszta chłopek z Nałęki. Odpowiedź tę na swoistą interpelację adoratora brzmi gorzko, ale też zaczepnie, i to właśnie w goryczy i prowokacyjności tej wypowiedzi ujawnia się nierozstrzygalność tożsamościowej gry, którą prowadzi za pomocą dziennika.

Demonstracyjna literackość tego dziennika wiąże się częściowo z pragnieniem przynależności jego autorki do tego, co uznaje ona za wysokie. Wyraża się również na poziomie treści (wyznawana przez nią idea czystej miłości, upragnione życie ideowca). Z drugiej strony możemy zaobserwować jej pogardę i brak zrozumienia dla tego, co niskie (utylitaryzm, pragmatyzm, zainteresowanie chłopcami itp.) przy jednoczesnym w to uwikłaniu. Pisanie, 
zarezerwowane dla klasy wyższej, ma być dowodem na jej niezależność od chłopskiego pochodzenia.

\section{Pierwsza miłość}

Jednym z aspektów literackości jest możliwość wyodrębnienia fabuły, która toczy się przez cały dziennik. Jest to historia relacji z chłopakiem, którą warto krótko streścić. Młoda, szesnastoletnia dziewczyna marzy o miłości. Nie interesują ją zaloty poznawanych przez nią chłopców, choć opisuje ich wielu; czeka na ideał, nawet gdyby miała go nigdy nie spotkać. Kiedy poznaje Roberta, ujmuje ją jego dystans do siebie, otwartość i miłość do Gałczyńskiego. Robert był „biednym malarzem”, co dobrze wpisywało się w jej romantyczne pragnienia. Zachowywał się w sposób swobodny i bezpośredni mimo dziwnego stroju - za małego granatowego garnituru.

- Wojtek wie, ale was muszę jeszcze trochę objaśnić, co do mojej osoby. Otóż oprócz ciała, reszta to nabytki muzealne. Ten garnitur to jeszcze od komunii. Mama kazała mi go włożyć, bo to do dziewczynki, więc trzeba się świątecznie ubrać. Podziwiałam go, że nic u niego nie kosztuje, to, co dla mnie byłoby nie do przyjęcia. (13.08.[1960], s. 16)

Podobało jej się, że potrafił, zachować autonomię wobec swojej rodziny i wiejskiego pochodzenia, jednocześnie nie odrzucając swoich korzeni, a przede wszystkim nie wstydząc się ich. Taka postawa była czymś, co sama Anna/Danuta chciała osiągnąć, ale co nigdy jej się nie udawało.

W taki sposób pojawia się w dzienniku wątek romantyczny - Danuta/ Anna zakochuje się w Robercie i jest to jej pierwsza miłość. Chłopak bardzo szybko okazuje jej swoje zainteresowanie. Danuta/Anna, mimo deklarowanych w dzienniku uczuć, zachowuje dystans, co spotyka się z niezadowoleniem Roberta. Notoryczne odmowy pocałunku okazują się dla niego problemem, z którym próbuje sobie poradzić szantażem emocjonalnym.

Chłopak bezskutecznie próbuje kontrolować sytuację, grożąc wycofaniem swojego zainteresowania. S. odrzuca jego awanse i, odpowiadając ostrym komentarzem, demaskuje mit romantycznej miłości.

- Śniłaś mi się w tę noc. Ciągle o tobie myślę, chociaż znam cię tak krótko.

Roześmiałam się głośno.

- To śmieszne co mówię [?] 
- Dla mnie tak, mów o czymś innym.

- Jaka ty dziwna i inna niż wszystkie.

- Dlatego, że śmieję się z tej recytacji, gdyż poznaję autora tekstu? (20.08. [1960], s. 19)

Danuta zdaje się świadoma, że jego zachowanie to konwencja, prosty rytuał, skrywający dominację za fasadą uczuć i szacunku", odgrywany przez mężczyzn próbujących zdobywać niedostępne kobiety. Ostatecznym, dramatycznym krokiem chłopca są oświadczyny, które nie tylko nie zostają przyjęte, ale odrzucone ze śmiechem. Czywiż/S. proponuje mu przesunięcie terminu oświadczyn o dziesięć lat.

Po tym wydarzeniu chłopak na jakiś czas znika z jej życia. Powraca do jej uczuć i myśli po kilku miesiącach, kiedy spotyka swoją dawną nauczycielkę, siostrę Marię, która także stanowiła dla niej obiekt miłosny. Uczucia do zakonnicy, które wydają się mieć homoerotyczny charakter, opisywane są na pierwszych kartkach dziennika:

Jutro przyjeżdża s. Maria.Żałuję, że ona nie jest mężczyzną. Jak to cudownie można by było kochać wtedy i cierpieć, a tak... Kocha się zakonnicę, do której można wzdychać, robić głupstwa, żeby zwrócić na siebie uwagę, grzeszyć, być bezczelnym i to wszystko...

Każdy kocha na swój sposób i kogo innego, a ja właśnie Ją, wysoką postać w białym habicie i szkaplerzu, o dużych niebieskich oczach i trochę pogardliwie wydętych wargach. I ten przyjemny gardłowy i drażniący głos. (21.02.[1960], s. 2)

\section{Uwikłana w płeć}

Podobnych sytuacji prezentujących dystans autorki do wyraźnie nią zainteresowanych młodych mężczyzn jest w dzienniku więcej. S. czerpie przyjemność z powodzenia i skrupulatnie zapisuje wszystkie jego przejawy. Mimo to wydaje się, że największe znaczenie mają dla niej opisy jej własnych reakcji na ich zainteresowanie. Z zadowoleniem przytacza swoje cięte riposty, prezentuje niezdarność chłopców i ich dezorientację. W każdej kolejnej historii młodzi

17 E. Illouz Dlaczego miłość rani. Studium socjologiczne, przeł. M. Filipczuk, Wydawnictwo Krytyki Politycznej, Warszawa 2016, s. 280. 
mężczyźni reagują podobnie - irytacją, groźbą użycia przemocy lub innymi zabiegami mającymi przywrócić równowagę, która zostaje zakłócona przez nienormatywne zachowanie Danuty S. /Anny Czywiż. Równowagę tę możemy, posługując się koncepcją Pierre’a Bourdieu, określić mianem porządku męskiej dominacji, według którego stroną aktywną jest zawsze mężczyzna. Męska dominacja wymaga od kobiet podporządkowania w ramach niewypowiedzianej zasady przystępności ${ }^{18}$.

Przysunął się jeszcze bliżej próbując zajrzeć mi w oczy.

- Takie mieć oczy jak ty... cholernie mi się podobasz i... Złapał mnie mocno za ręce.

- Nie tędy mój panie, bo...

- O, udowodnię ci, że jestem mężczyzną i właśnie cię pocałuję. Przyrzekłem to sobie wyjeżdżając z domu.

- Świnia z ciebie i więcej nic. Pospolita świnia! Puść idioto! (20.08.[1960], s. 19)

Przez odrzucanych mężczyzn zostaje zaliczona do grona dziwaczek, kobiet zimnych, zakonnic, dumnych hrabianek, świętych i niedotykalskich. S./Czywiż nie podporządkowuje się temu bezwolnie, umie zadbać o swoje granice, nie jest ofiarą. Nie dyscyplinuje samej siebie do wymogów tych aktów komunikacji. Mimo że jej sprawczość wywołuje podobne reakcje w podobnych sytuacjach, nie zmienia swojej postawy.

Istnieje jednak w postawie Czywiż/S. wyraźne napięcie między chęcią niezależności od uznania chłopców a ciągłym tego pragnieniem; chęcią poddania się przyjemności, jaka może płynąć z podporządkowania się normom. Jednak jest tego świadoma, co jest zilustrowane w poniższym fragmencie:

Biedne dziewczynki! Jakie wymyślne zabiegi, żeby właśnie tych, którzy tam stoją przyciągnąć do siebie, żeby zwrócić ich uwagę. Czuję, że gotowe byłyby zrobić wszystko, aby stać się podziwianym. Nie mogę normalnie na nich patrzeć i jednocześnie byłam zła, że to właśnie im chłopcy posyłają całusy. (7.05.[1960], s. 5)

Dziennik S. zdaje relację z uwikłania w płciowe zależności. Jednym z tematów, w którym to się silnie ujawnia, jest lęk związany z nieposiadaniem 
odpowiedniego wyglądu. Tym samym przedmiotem dziennika staje się kobiece ciało. Punktem odniesienia dla samooceny autorki jest, uznawana za piękność, młodsza siostra Basia. Anna/Danuta, przekonana o własnej nieatrakcyjności, nieustannie się z nią porównuje i jest porównywana przez innych, co wzmacnia jej doświadczenie ciała jako ciała nieatrakcyjnego.W jej postawie tkwi jednak pewne napięcie - obsesyjne powracanie do tematu własnej brzydoty, przeplatane jest z opisami ilustrującymi jej duże powodzenie u chłopców, choć, jak widzieliśmy powyżej, odrzuca zainteresowanych. Ocena własnej urody wydaje się nieadekwatna i przesadzona.

Autorka najczęściej opisuje te sytuacje, w których za ocenę jej urody odpowiada jej „niewłaściwe”, czyli „niekobiece”, zachowanie. Dostaje wówczas od otoczenia komunikaty: „Wiesz co Anka, ty jesteś trochę brzydsza od Baśki, bo się mniej śmiejesz" (3.07.[1961], s. 52). Mimo swej zwykle nonkonformistycznej postawy S. próbuje się dostosować, co możemy wywnioskować ze składanych samej sobie obietnic: „Nie będę już dłużej grać wesołej babki - jestem poważna i dlaczego mam się tak męczyć" (10.01.[1961], s. 39). Sytuację kobiet, której doświadcza również Czywiż/S., opisuje Pierre Bourdieu w książce Męska dominacja. Kiedy, używając terminu Bourdieu, nazwiemy tę sytuację zależnością symboliczną zobaczymy uwikłanie Danuty/Anny wyraźniej. Jest to „stan związanej z własnym ciałem ciągłej niepewności", wynikająca z męskich lub, ujmijmy rzecz szerzej, kulturowych oczekiwań podległości, dyskretności, delikatności, wycofania itp., które stawiane są kobietom a które ustanawiają kobiety w pozycji zależności wobec egzekwujących owe roszczenia ${ }^{19}$.

Paralelnie, oprócz zainteresowania osobników płci męskiej, rozgrywają się inne miłosne historie. Kilka jej koleżanek z internatu okazuje jej w różny sposób swoje płomienne uczucia. Danuta S. dzieli się tym ze swoim dziennikiem. Opisuje takich sytuacji bardzo wiele.

Ciągle piszą mi kartki z miłosnymi sonetami i wszystkie trzy zapewniają, że nikogo tak jeszcze nie kochały. Męczy mnie to i drażni. Zosia przysięgała /napisała to krwią na papierze/ na Boga, że do śmierci mnie nie opuści, będzie wszędzie za mną jeździła. Dodała, że tylko ksiądz ją może od tego zwolnić. (20.06.[1960], s. 13)

Wjej relacjach koleżanki zasypują ją kwiatami i pocałunkami, nie odstępują na krok, demonstrują zazdrość, troskę i oddanie. S. wielokrotnie wspomina, 
że męczy ją to i irytuje, ale jak sama pisze, nie daje tego po sobie poznać. Odrzuca uwielbienie dziewczyn w dość przewrotny sposób: przekonując je, że nie ma w niej nic wyjątkowego, że nie jest ideałem, który w niej widzą. Jej stosunek do tego nadzwyczajnego powodzenia nie zawsze jest negatywny.

Już wieczorem Anka napisała mi karteczkę: „Kochana jestem strasznie o ciebie zazdrosna i nie mogę patrzeć na tę głupią Zośkę, która cię ciągle obściskuje. Czy nie możesz jej odstawić od siebie? Ja tak piszę, ale ty mnie wcale nie kochasz, więc tego nie zrobisz, ale ja chcę ciebie mieć tylko dla siebie". Płakała tak i nie wiedziała, że właśnie ją lubię najbardziej z nich, kocham. A takie karteczki i nieporozumienia były pretekstem do czułych przeprosin wśród łez i pocałunków. A może my jesteśmy lesbijkami? (12.06.[1960], s. 10)

Zarówno jej reakcje na bycie obiektem tego uwielbienia, jak i jego treść stanowią przeciwwagę dla opisywanych przez nią interakcji z chłopcami. Uwypuklają znaczenie ich zachowania jako silnie powiązanego z płcią.

\section{"Czy jesteś nowoczesną dziewczyną?"}

W 1960 roku „Filipinka”, jedyne w owym czasie pismo dla nastolatek, zadało swoim czytelniczkom pytanie: „Czy jesteś nowoczesną dziewczyną?”.

Redaktorki „Filipinki” miały propozycje, kim taka nowoczesna dziewczyna mogłaby być. Była nią młoda kobieta, której zależało przede wszystkim na rozwoju intelektualnym, a która sprawy związane z seksualnością i konsumpcją odkładała na bok ${ }^{20}$. W odpowiedziach na pytanie „Filipinki” dominował wzór osobowy zbliżony do tego, który wyłaniał się z rubryk z poradami.

Chłopcy, jak z nich wynikało, nastawieni są na jak najwcześniejsze rozpoczęcie współżycia seksualnego. Redaktorki ostrzegały przed nieuchronną presją, jaka spotka dziewczyny z ich strony. Przekonywały do zaniechania fizycznej bliskości. Z drugiej strony odpowiedzialnością za przebieg znajomości młodych ludzi obarczały dziewczyny ${ }^{21}$.

\footnotetext{
20 M. Fidelis Czy jesteś nowoczesną dziewczyną? Młode Polki a kultura konsumpcyjna w latach 60., "Teksty Drugie" $2015 \mathrm{nr}$ 2, s. 315.
} 
Publicystka i pisarka Elżbieta Jackiewiczowa przekonywała, że młody mężczyzna będzie oczekiwał swobodnych kontaktów seksualnych, tylko jeśli dziewczyna go sprowokuje. Twierdziła, że istnieje „pewien typ zachowania", który skłania mężczyzn do wykorzystania dziewczyny do przypadkowego kontaktu seksualnego. Jackiewiczowa tłumaczyła,że młodzi mężczyźni marzą o prawdziwej i romantycznej miłości tak samo jak młode kobiety.„Ale muszą przecież wiedzieć, dla jakiej dziewczyny warto jest otworzyć serce". Co ciekawe, budując poprawny obraz nowoczesnej dziewczyny, czasopismo nie miało oporów, by przywołać przykłady właściwych relacji płciowych z XIX-wiecznych pozytywistycznych powieści, ponieważ „mimo nowoczesnych czasów problem płci jest ciągle ten sam. ${ }^{22}$

Kiedy porównamy lansowany przez „Filipinkę” wzór postępowania z chłopcami z perypetiami Anny Czywiż/Danuty S., uderzy nas ich duże podobieństwo. Wiemy, że autorka dziennika miała okazję czytać „Filipinkę”, ale nie wiemy, czy była jej wierną czytelniczką, gdyby jednak nią była, powiedzielibyśmy, że wzięła sobie porady jej redaktorek do serca.

Według Małgorzaty Fidelis „Filipinka” nie tylko lasowała te wzorce, ale była ich zwierciadłem. Na pytanie odpowiedziało listownie 200 dziewcząt w wieku 16-18 lat. Fidelis zwraca szczególną uwagę na

intrygujące połączenie starego z nowym. Wedle cytowanych w czasopiśmie listów nowoczesna dziewczyna była wykształcona i miała szerokie zainteresowania obejmujące kwestie polityczne, społeczne, kulturalne i ekonomiczne. Pogardzała ostentacyjną konsumpcją, najtrafniej ucieleśnianą przez „podskubaną, kolorową spódnicę zrobioną na drutach, włosy w kolorowe kosmyki”, „papieros w ręku i cyniczny grymas”. Jak pisała jedna z czytelniczek: „Ważny jest dla [nowoczesnej dziewczyny] szacunek, ambicja, godność". ${ }^{23}$

Małgorzata Fidelis przytacza fragmenty wypowiedzi dziewcząt i redaktorek „Filipinki”, które ukazują nam, w jaki sposób funkcjonował w wyobraźni społecznej wzorzec nowoczesnej dziewczyny albo w jaki sposób formował się nowy wzorzec kobiecości w okresie PRL. Problematyka podjęta przez Fidelis może stanowić jeden z punktów wyjścia dla interpretacji problemów 
omawianych w poprzedniej części tego tekstu; wyjaśniać powody zmagań Danuty S. Anny Czywiż.

Widzimy w dzienniku S. jeszcze inny aspekt dylematów związanych z połączeniem starego i nowego. Z jednej strony prezentuje ona „podmiotowość nastawioną na analizę własnych emocji”, skoncentrowaną na „zarządzaniu życiem uczuciowym i jego afirmacji”"24. Z drugiej zaś dzięki swoim lekturom podejmuje spóźnioną krytykę nowoczesności w duchu końca XIX wieku. Cytując Buddenbrooków Thomasa Manna, kieruje zarzuty wobec indywidualizmu:

Przez zakratowane okienko swej indywidualności beznadziejnie wyziera człowiek na mury otaczające świat, póki nie nadejdzie śmierć i nie powoła go do powrotu, do wolności... (4.10.[1961], s. 6o.

Przytoczony fragment dotyczy refleksji Tomasza Buddenbrooka, zainspirowanej lekturą Świata jako woli i przedstawienia Schopenhauera ${ }^{25}$. Jest to jeden z ostatnich wpisów w tym dzienniku, dlatego zestawiając tę krytykę z zaangażowaniem S. w pragnienie wyrażenia własnej niepowtarzalności i odmienności, możemy postawić tezę o rodzącej się przemianie i dojrzewaniu autorki dziennika. Napięcie między autonomią, indywidualizmem a potrzebą przynależności, które możemy śledzić w trakcie lektury, zmierza w tym punkcie ku rozwiązaniu.

\section{Religijność nowoczesnej dziewczyny}

Począwszy od 1949 roku, w Polsce była realizowana polityka ateizacji oświaty - dekrucyfikacja (1949), usuwanie religii ze szkół i wprowadzenie zakazu modlitwy przedlekcyjnej $(1954 / 1955)^{26}$. Religia katolicka została usunięta z życia publicznego, stając się sprawą całkowicie prywatną. Mimo to w społecznościach wiejskich religia była nadal bardzo istotnym elementem życia całej wspólnoty.

Wspólnotowy charakter religii łączył się ściśle z sygnalizowanym choćby przy okazji spowiedzi przekonaniem o zbiorowej współodpowiedzialności

E. Illouz Dlaczego miłość rani..., s. 21. 
wobec Boga za los całej grupy. Nic dziwnego, że w takim systemie myślenia wszelkie wyłamywanie się z ustalonych wewnętrznie norm i reguł odbierane było zatem w kategoriach "grzechu” bądź zagrażających bezpieczeństwu wspólnoty. ${ }^{27}$

Religia to dla Danuty S. pole gry w niezależność - od rodziców, od społeczności, z której się wywodzi. Odbiorcami tej gry są jej rodzice, jak i ona sama. Obserwuje własną religijność i, sądząc po datach wpisów, ma ona przebieg zmieniający się bardzo dynamicznie. 20 lutego 1960 roku zapisuje:

Bóg - oto najdoskonalszy ideał, a czy dążę do Niego? Czuję się strasznie winna, że nie potrafię żyć jeszcze tak, aby każda chwila była tym jednym krokiem, który mnie do niego bezustannie będzie zbliżał. (20.02.1960, s.1)

Ta żarliwa religijność sprawia wrażenie silnie powiązanej z uczuciem do siostry Marii. Kiedy uczucie to słabnie, wiara również zaczyna się chwiać.

$\mathrm{Z}$ moją religią coraz bardziej krucho. Boję się, że mogę zupełnie przestać wierzyć i będę wtedy b. nieszczęśliwa. Nie chcę być ateistą, nie chcę być niewierzącą, nie chcę, naprawdę nie chcę. Boże! Dlaczego tak się oddalam od ciebie, dlaczego ta odległość zwiększa się coraz bardziej? Dlaczego? Dlaczego? (16.05.1960, s. 6)

W kolejnym miesiącu pozawala sobie już na duże wykroczenie:

Spóźniłyśmy się na pół mszy, dwoje ludzi na krzyż. Stanęłyśmy w bocznej, ciemnej nawie, gdzie byłyśmy tylko obie. „Kościół to przecież to samo, co sala rekreacyjna, na której nieomal wszystko można robić". I żeby dowieść prawdy zaczęłam tańczyć krakowiaka boso, żeby nie wzbudzić niczyich podejrzeń. Sabina próbowała mnie naśladować i śmiałyśmy się tak, jak na dobrej komedii, a ksiądz „Dominus wobiskup”... (3.06.196o, s. 8)

Odmawia uczęszczania do Kościoła - przestrzeni, gdzie w powtarzanych cyklicznie rytuałach uczestniczy związana wspólnymi wierzeniami grupa ludzi; przestrzeni, w której „dzieje się" religia. Za pośrednictwem tańca w budynku kościelnym, performatywnie oznaczając w ten sposób to miejsce jako

Tamże, s. 262. 
nie-sacrum, stawia samą siebie poza nawiasem tej wspólnoty. Związany z religijnością kryzys - potrzeba wiary i nieadekwatność tradycyjnych form religijności do jej oczekiwań - rozwiązuje, znajdując dla siebie indywidualną formułę. Postanawia porzucić Boga babci, matki, siostry Matyldy na rzecz „własnego Boga”,który jest „najwyższą miłością”. Postanowienie to jest jednak dość przewrotne.

Trudno mi trochę żyć tak bez żadnego oparcia ani autorytetu. Niech więc istnieje ten Bóg prawdziwy, bo ja chcę wierzyć, ja muszę wierzyć. [...] Wiem, że w każdej dyskusji o Bogu będę manifestować swój kompletny ateizm, ale mimo że neguję życie pozagrobowe, istnienie ducha, będę się modliła do swojego Boga. (14.08.[1961], s. 58)

Jej postawa religijna zawiera dwa komponenty - prywatny, czyli potrzebę wiary, którą zaspokaja, stwarzając osobistego Boga, wychodząc poza instytucję Kościoła i publiczny, czyli prezentowany rodzinie i znajomym, ateizm. Mimo trudności z akceptacją swojego ateizmu, ,bezbożność” mogła być bardziej czytelnym stanowiskiem wobec religii niż jej poszukiwania „odpowiedniego" Boga i być może w tym należy szukać przyczyny decyzji o pozostaniu przy deklarowaniu ateizmu. Sitek prezentuje zupełnie odmienny stosunek do religii niż jej matka, dla której religijność ma funkcje społeczne i podlega ocenie społecznej. Wielokrotnie powtarza - rodzicom, koleżankom i zakonnicom z internatu - że wiara to jej sprawa osobista. Dlatego nie znajduje $\mathrm{z}$ matką porozumienia, kiedy ta nalega, żeby nie wychodziła z domu podczas mszy, co byłoby manifestacją braku uczestnictwa. Nie rozumie, że postawa matki nie jest zwykłą hipokryzją.

Matka funkcjonuje w polu religii - obiektywnym, instytucjonalnym, wspólnotowym, córka natomiast w polu religijności. Religijność w tym rozumieniu to zsekularyzowana potrzeba wiary. To formuła wiary refleksyjnej i prywatnej ${ }^{28}$. Religia ma znaczenie o tyle, o ile jest użyteczna „dla jednostek w ich życiu doczesnym, a esencji orientacji religijnej nie stanowi wiara, lecz doświadczenie i poszukiwanie doczesnej samogratyfikacji"29.

Postawa Danuty S. ma w sobie elementy zjawiska rozpoznawanego przez religioznawstwo i nazywanego „nową duchowością”, która definiowana jest 
jako wiara „tworzona przez jednostkę dla niej samej, w odpowiedzi na jej własne «duchowe potrzeby»". ${ }^{30}$

Materią, z której uszyta jest ta „duchowość na miarę”, jest przede wszystkim „przeżycie” (doświadczenie, emocja, uczucie). Wiąże się to ze „zwrotem ku doświadczeniu", konstatowanym już przez pierwszych teoretyków nowoczesności; zdaniem Baumana, koncentracja na „przeżyciu” jest główną cechą charakterystyczną płynnej fazy nowoczesności, postulatem kultury indywidualizmu i konsumpcji. Także i pojęcie duchowości wiąże się ze starym toposem „wewnętrznego doświadczenia”, przeciwstawionego „zewnętrznej”, ślepej wierze w dogmaty. ${ }^{31}$

\section{Zakończenie}

Dziennik Danuty S. wydaje się spełniać rolę, o której pisała Krystyna Kłosińska streszczając w książce Powieści o „wieku nerwowym” koncepcje Alaina Girarda na temat dzienników intymnych:

Dziennik jako gest zerwania ze światem społecznym, jest wyrazem skłócenia jednostki ze społeczeństwem, wyrazem nieprzystosowania do pełnienia jakiejkolwiek społecznej roli, a zarazem niezgody indywiduum na bycie sobą i na siebie samego, widzianego oczyma innych. ${ }^{32}$

Danuta S. wykonuje ruch ku emancypacji, nie tylko odrzucając oświadczyny, tradycję rodziców, spojrzenia mężczyzn itp. Dokonuje go również poprzez sam akt pisania w dwojaki sposób - jako chłopka, która sięga do tradycji (diarystyka) spoza kręgu swojej kultury, oraz rozpoznając siebie jako osobę twórczą. Pisze dziennik mający siłę literatury. Należy przy tym zauważyć, że pochodzenie autorki jest dla niej przedmiotem wstydu, który jednakże próbuje zwalczyć. Z drugiej strony chce pokazać, że nie warunkuje ono jej zdolności, wyglądu i zachowania. Dlatego teza o emancypacyjnej funkcji jej pisania jest problematyczna. Jeśli jest to wyzwolenie, to nie Danuty jako chłopki, odbywa się ono bowiem poprzez ucieczkę od pochodzenia.

Tamże, s. 210.

Tamże.

K. Kłosińska Powieści o „wieku nerwowym”, Śląsk, Katowice 1989, s. 85. 
Należy podkreślić, że mimo wszystko autorka nie jest jeszcze całkowicie wyobcowana z wiejskiej społeczności i rodziny. Jest bardzo młoda, ciągle więc pozostaje na utrzymaniu rodziców, a także jest z nimi związana emocjonalnie. Świadczy o tym natężenie konfliktów, w które z nimi wchodzi a które najczęściej dotyczą jej odmienności (często prowokowane są przez jej obrazoburcze manifesty).

Dziennik S. pokazuje próby, niekoniecznie udane, odnalezienia równowagi między oczekiwaniami społecznymi a zachowaniem autonomii na kilku polach jednocześnie: między chłopskimi korzeniami a nowymi aspiracjami; między przypisaną rolą płciową a pragnieniem osobistej ekspresji. Jednak zarówno ukierunkowanie na indywidualizm, jak i presja podporządkowania się normom przyczyniają się do jej cierpienia.

\section{Abstract}

\section{Anna Pawlik}

THE INSTITUTE OF LITERARY RESEARCH OF THE POLISH ACADEMY OF SCIENCES (WARSAW) The Diary of Danuta S. as a Class Identity Game

In the 1960s a number of organisations, including the Committee for Research on Modernity at the Polish Academy of Sciences, launched a diary writing competition as part of an extensive sociological research project. Sixteen-year-old Danuta S. submitted a diary that was not published in the anthology Młode pokolenie wsi polski ludowej [The Young Generation of Rural Areas in the Polish People's Republic]. Nonetheless, Pawlik demonstrates that this diary can be read as a field in which Danuta S. plays an identity game. This game, Pawlik argues, is realized through the diary writer's practice of recording and transcription. The diary shows components of a literary work, but its literary character is captured as an action aimed at self-identification.

\section{Keywords}

diary, journal, sociology, village, youth, identity, recording, transcription 